\title{
Article
}

\section{Threatening the Social Order}

\section{The Security - Morality Nexus in the Crisis of Capitalism}

\author{
Ana Ivasiuc \\ Philipps University Marburg
}

\begin{abstract}
One of the most productive loci for the analysis of the security - morality nexus is the making of security laws and norms which reveals the ways in which the social order is perceived to be under threat. This article argues for a critical examination of the moralities underlying the security paradigm, or else 'the securitarian moral assemblage', through the example of how the Roma are targeted by security laws, decrees, and measures in Rome. Moral values underpinning the social order become particularly visible in security laws, as these laws betray that which requires enhanced protection, and what is seen to produce the existential danger that jeopardizes the status quo. Taking a closer look at the practices that are framed as morally dubious and increasingly repressed and controlled helps us make sense of the moral underpinnings that serve the reproduction of a social order presaged upon exacerbated consumption and the production of inequalities. Such an approach goes beyond merely illuminating the dynamics of exclusion grounded in the racialization and discrimination to which the Roma are undoubtedly subjected. It establishes a link between the explosion of security narratives, practices, and measures, and the larger contemporary context of capitalism and the current protracted crisis that it has engendered.
\end{abstract}

\section{Keywords}

security, morality, law-making, Roma, nomadi, begging, Rome, Italy

\section{Introduction}

Security, since roughly the 1970 s, has increasingly become a weighty principle of social organization and a powerful technology used to legitimize and reproduce social order, leading to what has been called the 'security society' (Goldstein 2010 and 2016; Maguire et al. 2014; for a critical account of the presentism of this idea, see however Dodsworth 2019). Those at the bottom of social hierarchies are 
increasingly framed as public order issues and managed through security technologies and practices that punish, expel, expropriate, and ultimately attempt to exterminate (Wacquant 2009). Yet, the rhetoric of security alone and the accompanying 'culture of surveillance' (Lyon 2018) cannot effectuate such social structurations without a whole apparatus of moral constructions sustaining its work. Moral values are constantly mobilized to reproduce the social order by legitimizing and naturalizing particular practices. Moral worlds, then, intersect with security discourses and practices in a number of ways. If security talk is often used to justify morally contentious practices (Parsons 2020, this issue), it is also true that moralities always underpin security practices. Police officers tasked with policing subaltern groups and those who enact expulsions, arrests, deportations, or selections of deserving or undeserving immigrants, for instance, always ground their choices in morally charged constructions of threats to the nation or to public order (Heyman 2000; Fassin 2005 and 2011). The advocates for more surveillance and for impenetrable borders advance moral arguments in favor of protecting social orders seen as just and legitimate. Against the notion that exclusionary security practices are ontologically immoral - morality or immorality being always culturally and socially situated - I argue that security apparatuses are solidly grounded in evaluations of right / wrong and good / bad, that is, in values that implicitly contain moral judgments. Analyzing such underlying moralities is imperative if we are to understand how particular social worlds that exclude and exterminate subaltern populations garner support. Morality is neither purely antagonistic, nor epiphenomenal, but constitutive of security, and the examination of the moral underpinnings of security law-making points precisely to those practices that threaten the social order. The proliferation of security and the ferocity of exclusionary practices today are attempts to rescue the social order that supports capitalism in its deep contemporary crisis.

Despite its sustained ethnographic attention to morality (Zigon 2008), anthropology is yet to develop a coherent approach to morality as a crucial dimension of security in an age that is brimming with security talk. Attention to the moral underpinnings of the production of (in)security illuminates how and why security acquires particular discursive and non-discursive forms, or, in other words, the various vernacularizations of security (Bubandt 2005). The growing literature of the anthropology of security (Goldstein 2010 and 2016; Holbraad and Pedersen 2012; Moffette 2012; Maguire et al. 2014; Schwell and Eisch-Angus 2018) has explored the intersections between security and temporality (Holbraad and Pedersen 2013), space (Low 2003; Glück and Low 2017; Low and Maguire 2019), or aesthetics (Ghertner, McFann, and Goldstein 2020). However, little attention has been paid to the underpinning moralities in the production of (in)security in particular times and spaces, or, conversely, to the production of moralities through security laws, discourses and practices. This article conjoins the anthropology of security to the 
wide literature on the anthropology of morality (Howell 1997; Crandall 2004; Sykes 2009; Fassin 2012; Gsordas 2013) but explicitly connects the moral to the political (Mattingly and Throop 2018). It thus takes a stance against the idea that moral anthropology is a depoliticizing kind of scholarship (Kapferer and Gold 2018).

The nexus between security and morality is examined here through the ethnographic lens of how the Roma - or rather, nomadi - constantly cast as racialized moral outsiders, have been constructed and managed as a security threat, especially in the context of their migration from eastern Europe to Italy, starting in the 1960s. Through the analysis of law-making targeting directly or implicitly Roma, as well as an ethnography of contemporary formal and informal policing of Roma in Rome, I have examined the moralities that dictate their exclusion, repression, and increasing precarization in the name of security and public order. ${ }^{1}$ The first part of the article charts the ways in which the Roma have been framed as immoral and dangerous others in Italy, showing the relevance of taking antigypsy legislation as a locus for the analysis of the security - morality nexus. Consequently, I turn to the moral tenets of security laws and initiatives at national or local level, in Rome, around the contentious practices of begging and dumpster diving. Finally, the nexus between morality and security is conceptualized as a securitarian 'moral assemblage' (Zigon 2010) that sustains the contemporary recrudescence of repressive far-right ideologies in a time of heightened crisis of capitalism.

\section{The Gypsy as Immoral and Dangerous Other}

The framing of the Roma both as moral outsiders and as public order issue antedates the advent of the security paradigm as we know it. For Cesare Lombroso, famously, the Gypsies 'epitomize a thoroughly criminal race' endowed with moral shortcomings from laziness, cowardice, and promiscuity to ferocity, cruelty, and remorselessness (Gibson and Hahn Rafter 2006, 119). In 1889, a German member of the chamber was describing the appearance of a group of Gypsies as 'bold, nasty, immoral, and dangerous for security' (Illuzzi 2014, 107). In a sense, the Roma have nearly always been seen as a danger: their repeated expulsions and attempts to extermination attest this in European countries (Mayall 2004; Illuzzi 2014; Trevisan 2017), where their standing as 'folk devils' sparking moral panics has a striking continuity up to our days (Cohen 2011; Ivasiuc forthcoming). As such, the dynamics to which the Roma are subjected are particularly 'good to

\footnotetext{
${ }^{1}$ My research encompassed the ethnography of a far-right patrol mobilized to protect their neighborhood against property-related crime, as well as the ethnography of a police unit tasked with policing those seen as nomadi in Rome.
} 
think' the theoretical nexus between morality and security across geographical and historical contexts.

The othering of the Roma hinged on the mobilization of a particular moral arsenal that is historically and socially connected to the emergence of capitalism, on one hand, and of the nation-state, on the other. With the advent of capitalism, the law developed to protect private property and, with it, favor the propertied. At the same time, it aimed at discouraging and eradicating vagrancy, which implicitly signified the insubordination to wage labour. This marked the birth of the 'dangerous classes' (Wolf 1982), whose construction in the nineteenth century Western Europe relied heavily upon moral bordering (Scheu 2011). With 'Gypsies' being feared for petty crime - especially property-related crimes - and with the institutionalization of their representation and governance as vagrants, they embodied to perfection the two main enemies of the social order: the thief, and the vagabond. The figure of the latter, in particular, posed the threat of escaping the state's gaze and thus embodied a threatening stance of ungovernability. The representation of vagrancy as a threat has been particularly productive for the development of modern techniques of policing (Simoni 2011a): the intent to combat vagrancy lies at the very heart of the institution of the Carabinieri as military police in Italy (Piasere 2012). Similarly, the professionalization of the police in Germany was grounded in attempts to control the 'harmful tramps' that Gypsies were constructed as (Lucassen, Cottaar and Willems 1998). Piasere's observation that the birth of the modern state itself is grounded, among other things, in antigypsyism, is poignant (Piasere 2009, 53).

Many scholars attribute the origin of the stigma which has durably marked the Roma to the fierce attempts of the state to control labour force (Okely 1983; Lucassen, Cottaar and Willems 1998). In light of the social organization sustaining the development of capitalism in the European nation states, their representation has been as a people in perpetual clash with the law and hence outside of the realm of morality (Simoni 201 1b; Illuzzi 2014). On their part, Roma groups generally resisted both the project of subjection to wage labour, and that of allegiance to ethnically bounded nation-states. While capitalism and the nation state became hegemonic forms of social organization, they persevered in privileging both independent labour, and allegiance to extended family networks. Unsurprisingly, the practices of the Roma which have been and still are morally shunned and illegalized are those related to their often informal and marginal livelihoods, apparently inconsistent with the capitalist project. 
For its policy of governing the Roma through campi nomadi as unique housing solution, activists have coined Italy 'Campland' (ERRC 2000). ${ }^{2}$ The first camps appeared in the mid-sixties, following apparently well-intended efforts of non-Roma lobbyists to protect the 'nomadic culture' amidst the multiculturalist policies pressed by the Council of Europe. Nomadism was essentialized as the particularity of all Roma (Clough Marinaro 2003; Sigona 2005; Brazzoduro 2015; Picker, Greenfields and Smith 2015; Tosi Cambini 2015). However, (semi-)nomadism among certain groups of Roma, Gypsies and Travelers was an economic strategy more than a cultural trait: selling self-made household goods, providing maintenance services to household objects, or collecting iron scrap and reusable items, these groups' livelihoods were inextricably linked to economies of scarcity. Industrialization and the economic boom of the seventies, in the West, and forced collectivization and enrollment in wage labour, in the East, brought along a reconfiguration of the economies of these groups.

Although Roma is an umbrella term referring to heterogeneous groups, the differences between, say, Khorakhané or Xomà from Bosnia, Dasikhané or Kanjarija from Serbia, Cărămizari or Corturari from Romania, or Italian Rom abruzzesi or harvati are effaced both in policy and for Italian public opinion, for which they are all nomadi. In point of fact, the institution dealing with Roma-related issues in Italy changed its name from 'Ufficio Nomadi' to 'Ufficio Rom, Sinti e Camminanti' only in 2011. As these diverse groups would compete for the same spaces, economic opportunities linked to non-Roma, and positive image capital (Solimene 2011), lumping them together physically in camps has been disastrous. Physical proximity and economic competition spurred conflicts among groups that sometimes materialized in acts of vandalism and violence, thus reinforcing the imaginary of deviance and savagery that Italians have of Roma. Demonizing these groups en masse constituted the first step in their criminalization.

The camps materialized at the intersection of the exoticizing invention of nomadism, a sense of closeness to nature, but also dangerousness, criminality, and inadequacy to the moral norms of the sedentary society. Simultaneously, the supposed nomadism of camp inhabitants was subjected to civilizing interventions: the social projects implemented in camps since the sixties were meant to facilitate and normalize stable links with the territory through educational and employment projects (Bontempelli 2009a; Daniele 2011) as a corrective to the moral inadequacies that nomadism was supposed to bring along. To overcome them, children had to be socialized within the mainstream system of values and kept away from a

\footnotetext{
2 Although there are several types of campi nomadi according to their legal status and not few of them are informal settlements, the campi nomadi that I write of here are generally precarious encampments authorized or even established by the state, whose squalor is primarily the result of state neglect leading to the accumulation of waste, faulty or non-existent sewage, muddy paths, and precarious amenities.
} 
'culture of theft', whereas the adults had to be integrated into wage labour as a remedy for their supposedly innate work shyness. The camps thus became ambivalent policy dispositifs in which social engineering interventions were set up to combat the very nomadism they purported to protect. The logic of the camps dictated the isolation of their inhabitants far from Italian society and spaces in an 'urbanism of contempt' (Brunello 1996), unless they could be redeemed through moral improvement interventions that would render them innocuous. For the most part, though, public opinion saw them as unassimilable and culturally and morally incompatible.

Initially intended as temporary, the camps became perennial fixtures of governance of the most destitute Roma in Italy (Maestri 2019). Successive Roman administrations have gathered political capital and votes by promising to once and for all dismantle the camps that had long been objects of discontent among Romans. Political and economic interests to keep the system in place (Clough Marinaro 2015), a chronic affordable housing shortage, and fears of politicians to lose votes if they allocate resources to the unpopular zingari, however, led to the camps' permanence. Initiatives to assign social housing to Roma are often met with racism and violence, as in May 2019, when in the Roman peripheries of Torrenova and Casal Bruciato residents, incited by the far-right Casapound protested, and threatened the Roma with violence (Marani 2019). The message was explicit and consistent with the response of Romans to the settlement of Roma in their vicinity for the last fifty years: 'We do not want them here'.

The ambiguity of the camp in its imagined - desired, even - mobility and temporariness, but de facto stability and permanence, facilitates the othering of its inhabitants as dangerous. Mary Douglas (1991) famously theorized danger as that which is impure, with heterogeneous characteristics that problematize straightforward categorization. Many Romans are puzzled by the question of categorization: are the nomads transient, or not? And if they are nomads, why are they still here? The incoherent category of 'nomads' (Picker 2012) produces them not only as dangerous, but also as moral impostors: according to a neo-fascist supporter I interviewed during a 2015 protest in Rome, the Roma 'call themselves nomads, but [actually] aren't that nomadic' (si chiamano nomadi, ma tanto nomadi non sono). In a similar vein, a meme-like slogan often surfaces in far-right rhetoric demanding the dismantlement of camps: 'Se sei nomade, devi nomadare' - if you are a nomad, you have to 'nomadize'. In his 2008 electoral campaign, the soon to be mayor Gianni Alemanno plays with this ambiguity, asking: 'Are these nomads or not? If they're nomads, they should (...) leave!' (Stasolla 2012).

This categorical inconsistency transpires also in legislative acts. Following two episodes of moral panic surrounding Roma (Ivasiuc forthcoming), the Berlusconi government declared in 2008 a state of emergency related to the 'durable settle- 
ment' (my emphasis) of nomadi in the peripheries of Rome, Milan, and Naples. The emergenza nomadi was invoked using Italian legislation that prescribes the state of emergency in case of natural catastrophes. Since the presence of indigent Roma was not a natural catastrophe, and the measures undertaken were disproportional to any notion of danger, the decree was repelled in 2011 and the declaration of the state of emergency was deemed unconstitutional. Invoking the 'risk that [the situation] degenerates subsequently', the Minister of Interior had requested the adoption of extraordinary measures and the granting of exceptional powers to the Prefects of the concerned regions. Inhabitants of large campi nomadi, including children, were rounded up, counted, and fingerprinted - a practice that would also be declared illegal later on. The emergency legislation allowed the allocation of resources to the local administrations of the concerned regions in order to implement whatever measures they saw fit to combat the urban insecurity that the 'nomads' were thought to provoke. In Rome, this materialized in the establishment of a special police unit under the administration of far-right mayor Alemanno. Initially under the name Coordinamento Operativo Insediamenti Nomadi ('Operative coordinating unit for nomad settlements'), the unit was tasked with all actions of monitoring and controlling campi nomadi and carrying out evictions of informal settlements, as well as facilitating their transfer from the camps the administration intended to close towards authorized camps. Later on, the unit changed its name to Unità Organizzativa Gruppo Sicurezza Pubblica ed Emergenziale (SPE) - 'Unit for public and emergency-related security', which effectively obfuscated the fact that it was conceived as a racial police unit. Some of the sixty police that make up this unit have a longstanding experience of working in and around camps and have known some of the Roma families for over two decades. Although this prolonged contact with the Roma demonstrates that these families are nothing but sedentary, the police still maintain the stereotype of nomadism, referring to the camp inhabitants mainly as nomadi, or, with a racial slur, zingari. For the police, nomadism is at the core of the deviant nature that they attribute to camp inhabitants, in a circular logic. The police that I interviewed or accompanied on patrols around the camps in 2015 and 2016 were eager to explain the link that they saw between criminality and nomadism:

'Of course, they are criminal, this comes from being nomadic. Why would you want to be constantly moving around if you didn't have something to hide from the authorities? You do something wrong somewhere, and run away, you escape and that's how you get away with it. They're always on the run like that, to escape. Why can't they become sedentary, have a normal job like everyone else, send their kids to school, pay their taxes, their expenses, and so on? Because they're criminal, ninety percent of them are!' 
The categorical anomaly of the Roma as permanently settled 'nomads' is also reflected by the police discourse, as another officer would explain:

'If it was up to me, I would put in place a system where each family could stop for a period of time, one-two years at the most, but then they would have to leave again. I'm all for respecting nomadic culture, but then it has to be a real nomadism. What kind of nomad are you if you've been in Rome for forty years?!'

My efforts to explain that the Roma in Italy - or eastern Europe, where a large share of the Roman camp inhabitants come from - have ceased to be nomadic for at least three generations were met with disbelief: 'Why do they live in camps then?'

Camps thus solidify and perpetuate the Orientalist imaginary of nomadism, becoming governing technologies that effectively 'nomadize' the Roma (Sigona 2002, 2003 and 2005; van Baar 2011), exacerbating ideas of cultural difference and moral incompatibility, and feeding the most brutal kinds of biological racist ideas. Not seldom did I hear Italians say during my research that delinquency, like nomadism, and like the squalor that one can see in camps, are 'in the blood' of the nomadi.

Failure to live up to the idea of nomadism that Italians have of the Roma portends the breach of a contract stipulating rigid identities and the unambiguous separation between the nomad and the sedentary, and the performance of such identities along the expected scenarios. Non-conformity to these expectations becomes an 'epistemic inconceivability' (Scheu 2011) experienced as a moral transgression. It is through such constructions that the Roma are confirmed in the social imaginary as immoral tricksters, a recurrent and obstinate figure (Piasere 2011) that becomes an object of targeted control, repression, and expulsion. In this process, the law has a decisive role.

\section{The Moral Underpinnings of Security Law-Making}

Law encapsulates ideas about right and wrong. As such, it is one of the most productive lenses for the analysis of how moral values are negotiated between various positions and translated into governmental practices. Moral shifts become visible through new legislation. Legal scholars have argued that the law encodes asymmetric social relations and legitimizes the social order, functioning as an instrument for social reproduction (Nader 2002; Goodale 2017); critical race theory emphasizes this in the case of racial subordination (Möschel 2014). Moral values that underpin the social order become particularly visible in security laws, as these laws betray what requires enhanced protection, and what is seen to jeopardize the 
status quo. The proliferation of security laws then is a sign that the social order they protect is increasingly unstable. It follows that recent security laws and their making can tell us something about the dynamics of social change that amount today to the rise of the far right and to the heightened control, repression, and exclusion of various Others.

The Roma have been continuously recast as 'the other of the law' (Fraser 2001; Simoni 2005). In Italy, like in other contexts, there is a long genealogy of securitization through legal measures: for the first time, the Roma were framed as a threat in Rome in 1522, when the governor issued a ban in which the link between Gypsies (zingari) and delinquency was for the first time explicit (Coccia 2012). In 1914, the judge Alfredo Capobianco (1914) wrote his book The Problem of a Vagrant People in Conflict with the Law where he offers a snapshot of how they were considered a threat to 'civility', security, and social norms over a century ago. Reading the book today provides us with a distinct sense of permanence of the Roma's framing as delinquents, through the ethnicization of petty crime as 'gypsy delicts' (delitti zingareschi) then, and as 'nomads criminality' (criminalità nomade) today.

Much has been written about how the Roma are targeted by Italian laws and the judiciary through the lens of criminality. Writings on this topic (for instance Tosi Cambini 2008 and 2011; Fiorita, Giolo and Re 2010-2011; Bonetti, Simoni and Vitale 2011) multiplied as a result of a series of legislative acts in which the Roma were either explicitly, or implicitly central as figures of public threat (Simoni 2008). When they were only implicitly targeted by laws, Simoni (2010-2011) shows, antigypsyism was explicit in the bills conducive to the texts that were ultimately adopted.

The emergenza nomadi legislation of 2008 set in motion a process of ruling though local decrees that would be generalized across Italy later, with the 2009 security law: municipalities in the concerned regions received discretionary powers to combat urban insecurity and to implement whatever measures they saw fit. So, it came, for instance, that mayor Joe Formaggio of the northern Albettone prohibited in all impunity the entrance of nomadi on the territory of his municipality. Kebab shops and internet outlets in Lega Nord-ruled towns were closed down. Under the cover of 'preventing and eliminating serious dangers that threaten public safety and urban security' (Trucco 2008), in many places - including through a remarkable absurdity Assisi, the birthplace of Saint Francis, creator of the mendicant order of monks - begging was prohibited altogether (Bontempelli 2009b).

I want to focus here on two particular topics of concern that have been spurring debate and regularly resurface either in various legislation, or in negotiations around the kind of legislation needed to tackle them. Both topics relate to marginal forms of livelihood that the most destitute Roma in Rome (and elsewhere) 
have been practicing: mendicity, on the one hand, and the rooting through dumpsters in search of reusable items, on the other. Both are connected to a notion of moral and material decay and urban blithe (degrado), which in turn is closely linked to a sense of insecurity. When asked about the purported 'lack of security' that lied at the core of a citizen mobilization against campi nomadi in May 2015, for instance, a member of a Roman neighbourhood committee explained:

'Lack of security because unfortunately we, citizens, have gotten to the point that we are not free to live [in] our own neighbourhood at any time of the day or of the night, but especially in the evening and at night [people] are afraid to get out of their houses because of the continuous acts of microcriminality muggings, pickpocketing, thefts - and of a situation of general blithe (degrado generale) where there is mendicity, dumpster diving (accattonaggio, rovistaggio).'

\section{Mendicity (Mendicità or accattonaggio)}

Begging has multiple forms, some more or less dissimulated as exchange - such as selling free newspapers, busking, or cleaning windscreens: a continuum of practices. Begging and vagrancy have been historically associated and the subject of numerous laws targeting Roma and other marginal peoples across various geographical and historical contexts. Just like in the case of nomadism, Italian jurisprudence has often culturalized mendicity as a 'tradition' of the Roma - in particular when children are involved (Ruggiu 2016). But mangel - as it is called in Romani - is only practiced when other sources of income are unavailable or to complement income otherwise insufficient; historical evidence suggests that access to economic wealth results in the abandoning of begging as a livelihood (Piasere 2004).

Public attitudes against begging, like those against vagrancy, have worsened with industrialization and the rise of capitalism. In Rome, panhandling has increased in frequency over the last decades; in the capital city of Catholicism, mendicity is played out as an exchange involving both the performance of piety and the practice of charity (Thomassen 2015). However deep the Christian roots of charity, begging is at the heart of a cluster of contentious practices that have been the object of disputes in law-making and public debate.

The unease with certain forms of mendicity stems from a breach of rules surrounding the notion of the gift as voluntary giving: Piasere (2009, 104-5) shows how the non-Roma view begging with unease because it involves asking for a gift. It turns charity - that should be the giver's initiative out of the goodness of his or her heart - into a response to a request made by another. It problematizes thus the free will to engage in an exchange that, if initiated, would emphasize both the 
moral qualities of the individual, and his or her superior social standing. Moreover, the expected scenario for mendicity emphasizes the indigent person as a passive receiver, and the giver as a moral agent. Begging with composure, therefore, and performing indigence with humility is acceptable; the more insistent the act of asking for alms is, the more unease it produces, because it diverges from the prescribed scenario and turns social hierarchies on their head. If begging is a redistributive practice, emphatically asking for alms is a political revendication of the subaltern. No wonder, then, that when the social order is perceived as threatened it becomes dangerous and hence an object of concern for law-making.

Sabrina Tosi Cambini (2017) offers an elegant reading along these lines. For her, mendicity is 'an economic practice of asking (chiedere) (...) that continuously evades the dominant social and economic relations and for this reason may contribute to reconfigure them' (117). Mobilizing the concept of 'negative reciprocity' (Narotzky and Moreno 2002) as a rupture in the moral order of a world defined by exacerbated inequality, she argues that begging is grounded in a relationship of negative reciprocity in which the parties engaged are morally distant and the subaltern refuse to participate in the hegemonic morality that obfuscates relations of exploitation. Begging, then, becomes a demand for the redistribution of resources, acquiring thus a forceful political dimension (122).

The legal treatment of panhandling is revealing diachronically. Begging was altogether criminalized in the penal code produced between 1925 and 1930 under fascist rule (the Rocco code), to be depenalized only in the nineties. The only practice that remained a violation was involving children in begging, considered a misdemeanor (contravvenzione) for which the punishment ran from three to twelve months imprisonment. The security law of 2009 (94/2009) turned child begging into a felony (delitto) of the parents or legal custodians 'against the person' and increased the punishment threefold, adding the automatic loss of parental custody rights. ${ }^{3}$ The most recent security law (132/2018) strengthened the link between organized crime and begging, sanctioning those who participate in the organization of panhandling as a usual lucrative activity. It also added two more offenses: the notion of accattonaggio molesto (bothersome begging) reintroduces as a felony what in the Rocco code was a misdemeanour called 'intrusive begging' (mendicità invasiva) which had been abrogated in 1999. Moreover, it sanctions forms of mendicity that use 'fraudulent means.' In other words, begging must be performed by single, unorganized individuals out of a real economic need, and not as labour that requires group organization (on this, see Tesăr 2015). The means to obtain alms must concord with the performative script of social hierarchies, with the expectation of honesty and humility from those who beg. The 'simulation of defor-

3 On how the obstinate questioning of the Roma's parental abilities and educational model leads to Roma children being disproportionately and abusively taken into state custody, see Saletti Salza 2014. 
mity or disease' or the use of 'fraudulent means' betray an imaginary of bodily and moral imposture that is not only common in the suspicion with which Roma are generally met on grounds of their ethnicity, but also, as James Scott (1987) reminds us, a reasonable expectation from the dominant that the subaltern is always, in some way, trying to cheat - in other words, there is always the suspicion that the subaltern attempts to overthrow the social order. As to what precisely 'bothersome begging' means, the notion is treated as self-evident, without further definition. The recurrence of subjective terms that remain undefined in the law, Tosi Cambini $(2017,128)$ argues, is the sign that we are faced with a cultural hegemony at work: the hegemony of a particular aesthetic urban and social order (Ivasiuc 2019a).

\section{Rooting through Dumpsters}

Another marginal livelihood of the Roma is the repurposing and sale of used objects found in dumpsters on second hand, often informal markets. This is a practice that regularly produces all sorts of moral outcry around concerns for children's exploitation and hygienic matters, and deep repulsion. ${ }^{4}$

The practice of dumpster diving (rovistaggio) recurrently reaches the political agenda of Rome's municipality. In 2008, as an article in La Repubblica on the 6th of August reports, during an extraordinary council meeting on security, a centre-leftwing councillor of the liberal democrat party raised the issue of the 'hygienic and sanitary risks' which the practice poses in the urban space, urging the mayor to pass an anti-scavenging decree (ordinanza anti-rovistaggio) to penalize the practice. The article recognizes that the measure, if adopted, would hit hard in particular 'the vagrants and the nomadi'. At the time, non-governmental organisations, in particular the Catholic Sant'Egidio community, blocked the proposal on grounds that the phenomenon - at any rate marginal - would affect the poor, the elderly indigents, and the homeless of Rome, de-ethnicizing the issue and advocating for anti-poverty instead of repressive measures.

The debate on rovistaggio resurges recurrently and passionately in Rome. Photographs of Roma or immigrants at work often circulate on social media and elicit violent reactions ranging from abjection to criminalization (Ivasiuc 2019a). At any given moment, several neighborhood committees and lobbies are petitioning for the introduction of strict regulations. In 2013, for instance, the organization for the protection of consumers - Codacons - filed a complaint to the Public Prosecutor and a letter of formal notice to the municipality. Calling rovistaggio 'an unacceptable form of blight' (degrado), the association argued that it could amount to more serious criminal offenses: since rubbish is considered property of the munic-

\footnotetext{
${ }^{4}$ For an ethnographic account of the practice and the logistic, spatial, and symbolic tactics of Roma waste traders in Rome, see Clough Marinaro 2018.
} 
ipality, it falls under property theft. Also, since documents containing personal data may be improperly disposed of, it could potentially lead to identity theft and the fraudulent use of personal data. That rubbish, a sort of public 'good' since it belongs to the municipality, may encapsulate the danger of identity theft, is telling of the exaggeration of security concerns, and of their instrumentalization in antiRoma lobbying and the governance of Romani livelihoods. It is, moreover, indicative of how ' $[t]$ he mythology of identity theft actively structures new relations of social control' while leaving deep structural inequalities unattended to (Monahan 2009, 156). The measure is proposed 'to protect the city's decoro' ('a favore del decoro della citta'), a notion of aesthetic propriety of bourgeois sensibility closely related to material order but also with moral inflections of 'decency'. I have noted elsewhere (Ivasiuc 2015) how the notion of urban blight (degrado) structures the insecurity discourse in the Roman peripheries, agglutinating notions of material decay and disorder with the social and moral decadence of a once great empire. In the security aesthetic, decoro is posed as the order to be protected against the blight and decay that various figures of the Other are thought to bring to the city. The argument of Codacons, in fact, is mobilized to erase manifestations of poverty from view in the urban space, attempting to regulate urban décor according to the neoliberal aesthetic of capital and consumption (Gerrard and Farrugia 2014).

The conjunction of security and decoro - what has globally been noted as the recent 'obsessed politics of neighborhood civility-and-security' (Comaroff and Comaroff 2016) - transpires from institutional arrangements, too, with the recent proliferation of municipality and police departments called Sicurezza e decoro urbano, and legal norms at national and local levels. Many of the local measures taken in the name of security after the 2009 law were aimed at protecting this notion of decoro, penalizing innocuous things such as graffiti, carrying duffel bags, feeding stray dogs, socializing with sex workers, or lying on benches. Some municipalities have also issued decrees that indeed penalized rovistaggio.

To increase the punishment for rovistaggio, the organization proposes as aggravating circumstance the 'customary or necessary exposure to public trust' ('aggravante per cose esposte per consuetudine o necessità alla pubblica fede), that is, that the objects were taken from public space. Rather than being a punitive exaggeration of the practice's gravity, this framing implicitly gestures at its power to undermine the most basic forms of trust (fede) that glues the social together, and with it, the existing social order under consumer capitalism. The framing of the content of dumpsters as rubbish invalidates the possibility of its reuse. What one discards in the age of planned obsolescence becomes waste (immondizia) and should remain so: rescuing anything from this category, then, becomes theft and constitutes a boundary transgression. This ambivalent framing confirms the social constructedness of waste and the ideologies at play in the negotiation of social inequality in Rome (Clough Marinaro 2018). Under this vacillation between waste and property lies an ideolo- 
gy in which consumption and disposal are inseparable. The attempts to outlaw salvaging are intent to protect a social order presaged on the tireless cycle of consumption, discard, production, consumption that constructs social boundaries between those who can afford to consume and discard at will, and those who cannot. Behind the practice of salvaging reusable objects from waste lies the threat of a new kind of economy - not new as in never heard of, but new as in promising a paradigmatic shift, a counter-hegemony to consumption capitalism grounded in environmentally responsible and more solidary forms of consumption. ${ }^{5}$ Should this economic order become dominant through a veritable grassroots movement, it threatens to set in motion a tectonic reconfiguration of production and of the social relations underpinning it.

\section{The Moral of the Story: The (Im)Morality of Threatening the Social Order}

In times of security, the Roma are subjected to protracted dynamics of racialization and exacerbated difference (Daniele 2010) that translate into laws and legal norms. The example of the Roma illuminates particularly well the nexus between security and morality. In my research, I have noted how in the 1980s, the word 'sicurezza', meaning both safety and security, was very sparsely used in Italian media, and how it connoted exclusively a notion of bodily integrity rather than 'security' as we know it today. The debates of the time revolved around the safety belt and labour safety, to cite the most recurrent themes, and law-making around sicurezza was concerned with road and air travel safety, although political terrorism and violent organized crime were rampant. Over less than two decades, sicurezza morphed into a notion of collective security and was increasingly linked to the survival of communities - in particular the nation - and of the culture they embody. Not coincidentally, one of the first domains to be securitized globally was immigration, starting with the 1990s. The puzzling question as to how this shift happened, and how to explain the creeping up of insecurity in all domains of life necessarily needs to consider the shifts in moralities that allowed for the rise of the security paradigm, one in which securitarian moral assemblages immoralize subaltern groups while at the same time securitizing them.

This article took the law, together with the negotiatory processes conducive to legal norms, as the locus for the analysis of the security - morality nexus. Local de-

\footnotetext{
5I do not wish to romanticize the circular economy, or its promises. Ironically, the Città dell'Altra Economia in Rome, a consortium of companies promoting fair trade, respect for the environment, equal distribution of value, and the principle of 'people before profit and growth' has been established on the site of the Mattatoio, replacing one of the oldest informal campi nomadi evicted in 2007 amidst dynamics of gentrification that have been referred to as the 'de-gypsification' of Rome (Bermann and Clough Marinaro 2011). Although the website delves into the history of the Mattatoio, there is no mention of the Roma who occupied the space for over twenty years and were seen as an example of 'integration'.
} 
crees adopted in the name of security and public order, security laws, and public debates that pushed legislators to formulate security measures uncover the perceived threats of the time and the way in which they are evaluated against notions of good and bad, legitimate and illegitimate, right and wrong. But such moral judgments that transpire into laws and norms are socially situated at the top of power hierarchies. Through moralized constructions of danger, it is the powerful who protect the social order that they dominate, reproducing its sensibilities in narratives of propriety, order, and decency. Against these, practices such as begging or salvaging to repurpose objects become intolerable cracks in the social order built around unbridled consumption and inequality.

Given the centrality of consumption to the social order produced by capitalism, the link between security and consumption is powerful (see also Kuldova 2020, this issue). The growing body of literature on surveillance capitalism (Zuboff 2019), on the one hand, and on authoritarian capitalism (Bloom 2016), on the other, illuminates the robust connection between consumption and the rise of authoritarianism in the security-cum-surveillance paradigm. But the levels of inequality exacerbated over the last decades are no longer tenable, socially and politically. Our production and consumption patterns have proven dramatically unsustainable in the age of the Anthropocene, or, what some have called 'Capitalocene' (Moore 2017). Recent analyses indicate that if the current trend of accumulation by the $1 \%$ richest continues, they will own two thirds of the globe's resources by 2030; by then, coincidentally, the planet's temperatures will have risen by the crucial 1.5 degrees Celsius above pre-industrial levels that presages planet-wide destruction and food shortages. That we are faced with a crisis is undeniable. A crisis of capitalism, certainly, but also of the social organization sustaining capitalism. It is to this crisis that we can attribute, at least in part, the proliferation of security and surveillance, and the contemporary protracted repression of subaltern groups.

The hegemonic moral order that legitimates capitalist accumulation at the expense of the vast majority and of the planet seems to be on the verge of breaking. There is growing disenchantment with a system that produces so much inequality and environmental damage. Under the pressures of growing precarization, the waning middle-class has a volatile power to enforce particular moral discourses linked to the productive repertoire of (in)security. Pendulating between the perceived powerlessness in face of uncontrollable forces (EU-ification, globalization, immigration, waning national sovereignty) and the privilege derived from the ability to skillfully manipulate cultural hegemonic vocabularies and mobilize power, it finds itself in an unstable subject-position. We could argue then, with Jean and John Comaroff (2016), that a society obsessed with crime is one that no longer understands itself. Perhaps. But it is one that understands the significance of the 'little security nothings' (Huysmans 2011) that crunch, day by day, at the existing 
social order, pushing against the boundaries of prevalent norms and opening up spaces and possibilities of being-in-the-world otherwise.

A romanticizing view of these possibilities is, however, far from what I intend to depict. In the struggle for shaping other ways of being that run counter to the hegemony of brutal capitalism, on the one hand, and of the nation state, on the other, the Roma - just like the poor and other racialized subalterns - pay the high price of continuous repression and exclusion that make their lives 'nasty, brutish, and short', as Hobbes would have it. But the Leviathan has evidently failed the promise of ensuring the survival and protection of all, and the increasingly central debates around the introduction of a universal basic income, degrowth, or the abolition of racial inequalities testify of forces that seek alternative worlds to the one we know.

Legal scholars have criticized Italy's aberrant preservation of the penal code from the fascist era and the conservative tendencies regarding various attempts to update it. For some, it reveals a fascination with authoritarianism (Palazzo 2011). In the nineties, a series of petty offenses like begging were depenalized, but today we witness their return among popular concerns and objects of the law. That notions from the code produced by the fascist era resurface in today's prolific security legislation is worrisome, to say the least. But perhaps those alarmed by begging or dumpster diving are right: seen as such, acts that challenge the status quo and the social and economic organization that capitalism has engendered no longer seem petty. They render visible the cracks of the system and pave the way for those acts of resistance to precarization and extermination that are the most pertinent social critique of our times. Therein lies the possibility of negotiating new worlds and new moral orders.

\section{Acknowledgments}

Data for this article was collected within the project 'Dynamics of Security: Forms of Securitization in Historical Perspective' (SFB-TRR 138), funded by the German Research Foundation and carried out at the Justus Liebig University Giessen, the Philipps University and the Herder Institute for Historical Research on East Central Europe Marburg. A draft version of the article was presented at the conference of EASA's Anthropology of Security Network held in Oslo between 28-29 March 2019. I thank the organizers of the conference for their support and feedback, as well as Tereza Østbø Kuldova and Jardar Østbø, and the reviewers for their very useful comments. 


\section{Author Bio}

Ana Ivasiuc is a social anthropologist affiliated with the Center for Conflict Studies of the Philipps University Marburg, Germany. Her research areas range from Roma-related issues (development, activism, mobility, securitization) to the anthropology of security, conflict, formal and informal policing, and urban ethnography. She is the winner of the 2017 Herder-Council for European Studies Award, and the co-editor of Roma Activism: Reimagining Power and Knowledge (with Sam Beck, Berghahn Books, 2018) and The Securitization of the Roma in Europe (with Huub van Baar and Regina Kreide, Palgrave Macmillan, 2019). Ana is currently a co-convener of EASA's Anthropology of Security network, and a social media editor for the Anthropological Fournal of European Cultures. She is currently undertaking a comparative ethnography of German and Dutch civil defense groups funded by the Gerda Henkel Foundation's Special Programme 'Security, Society, State'.

\section{References}

Bermann, Karen, and Isabella Clough Marinaro. 2011. "Exclusivity and Exclusion: Roma Camps and the 'Degypsification' of the Roman Urbs." Public 43:62-75.

Bloom, Peter. 2016. Authoritarian Capitalism in the Age of Globalization. Cheltenham and Northhampton (MA): Edward Elgar Publishing. https://doi.org/ $\underline{10.4337 / 9781784713157 .}$.

Bonetti, Paolo, Alessandro Simoni, and Tommaso Vitale (eds.). 2011. La condizione giuridica dei Rom e Sinti in Italia. Milan: Giuffrè.

Bontempelli, Sergio. 2009a. "Le frontiere dell'identità: I rom rumeni in Italia." In Intercultura, nuovi razzismi e migrazioni, edited by Ilaria Possenti, 149-68. Pisa: Plus.

_. 2009b. “'Ordinanza pazza.' I Sindaci e il versante grottesco del razzismo." In Libro bianco sul razzismo in Italia, edited by Grazia Naletto. Rome: Manifestolibri.

Brazzoduro, Marco. 2015. "Prefazione: Un'etnia senza un volto e senza una voce." In Vincere il confine, edited by Adriana Goni Mazzitelli, 14-17. Rome: Aracne.

Brunello, Piero (ed.). 1996. L'urbanistica del disprezzo: Campi rom e società italiana. Rome: Manifestolibri.

Bubandt, Nils. 2005. "Vernacular Security: The Politics of Feeling Safe in Global, National and Local Worlds." Security Dialogue 36(3):275-96. https:// doi.org/10.1177/0967010605057015.

Capobianco, Alfredo. 1914. Il problema di una gente vagabonda in lotta con le leggi. Naples: Raimondi. 
Clough Marinaro, Isabella. 2003. "Integration or Marginalization? The Failures of Social Policy for the Roma in Rome." Modern Italy 8(2):203-18. https:// doi.org/10.1080/1353294032000131247. . 2015. "The Rise of Italy's Neo-Ghettos." Fournal of Urban History 41(3):368-87. https://doi.org/10.1177/0096144214566958. . 2018. "Salvaging Rome: Roma waste traders and the city's 'garbage crisis'." Etnografia e Ricerca Qualitativa 1:11-31.

Coccia, Benedetto (ed.). 2012. 'Zingari': Storia dei nomadi a Roma tra accoglienza e rifiuto. Rome: Apes.

Cohen, Stanley. 2011 (1972). Folk Devils and Moral Panics. 3rd ed. London and New York: Routledge. https://doi.org/10.4324/9780203828250.

Comaroff, Jean, and John Comaroff. 2016. The Truth about Crime: Sovereignty, Knowledge, Social Order. Chicago: University of Chicago Press.

Crandall, David P. 2004. "Knowing Human Moral Knowledge to Be True: An Essay on Intellectual Conviction." Fournal of the Royal Anthropological Institute 10:307-26. https://doi.org/10.1111/j.1467-9655.2004.00191.x.

Csordas, Thomas. 2013. "Morality as a Cultural System." Current Anthropology 54(5):523-46. https://doi.org/10.1086/672210.

Daniele, Ulderico. 2010. "Censimenti e razzializzazione della differenza zingara nell'era della sicurezza." In RelativaMente: nuovi territori scientifici e prospettive antropologiche, edited by Luigi M. Lombardi Satriani. Rome: Armando \& Armando.

- 2011. Sono del campo e vengo dall'India: Etnografia di una collettività rom ridislocata. Rome: Meti.

Dodsworth, Francis. 2019. The Security Society: History, Patriarchy, Protection. London: Palgrave Macmillan. https://doi.org/10.1057/978-1-137-43383-1.

Douglas, Mary. 1991[1966]. Purity and Danger: An Analysis of the Concepts of Pollution and Taboo. London and New York: Routledge.

ERRC (European Roma Rights Centre). 2000. Campland: Racial Segregation of Roma in Italy. Country Report Series nr. 9, available at http://www.errc.org/uploads/upload en/file/00/0F/m0000000F.pdf. Accessed June 15.

Fassin, Didier. 2005. "Compassion and Repression: The Moral Economy of Immigration Policies in France." Cultural Anthropology 20(3):362-87. https:// doi.org/10.1525/can.2005.20.3.362.

- 2008. "Beyond Good and Evil? Questioning the Anthropological Discomfort with Morals." Anthropological Theory 8(4):333-44. https://doi.org/ $10.1177 / 1463499608096642$.

-2011. La force de l'ordre. Une anthropologie de la police des quartiers. Paris: Seuil. - (ed.). 2012. A Companion to Moral Anthropology. Oxford: Wiley Blackwell. https://doi.org/10.1002/9781118290620.

Fiorita, Nicola, Orsetta Giolo, and Lucia Re (eds.). 2010-2011. Jura Gentium: La 'minoranza insicura': I rom e $i$ sinti in Europa VIII. 
Fraser, David. 2001. "To Belong or Not to Belong: The Roma, State Violence and the New Europe in the House of Lords." Legal Studies 10, 21(4):569-93. https://doi.org/10.1111/j.1748-121X.2001.tb00181.x.

Gerrard, Jessica, and David Farrugia. 2014. "The 'lamentable sight' of homelessness and the society of the spectacle." Urban Studies 52(12):2219-33. https://doi.org/10.1177/0042098014542135.

Ghertner, D. Asher, Hudson McFann, and Daniel M. Goldstein. 2020. Futureproof: Security Aesthetics and the Management of Life. Durham (NG): Duke University Press. https://doi.org/10.1215/9781478007517.

Gibson, Mary, and Nicole Hahn Rafter, trans. 2006. Criminal Man, by Cesare Lombroso, 2nd edition. Durham and London: Duke University Press.

Glück, Zoltan, and Setha Low. 2017. "A Sociospatial Framework for the Anthropology of Security." Anthropological Theory 17(3):281-296. https://doi.org/ $10.1177 / 1463499617729229$.

Goldstein, Daniel. 2010. "Toward a Critical Anthropology of Security." Current Anthropology 51(4):487-517. https://doi.org/10.1086/655393. . 2016. "Some Thoughts on the Critical Anthropology of Security." Etnofoor 28(1):147-52. http://www.jstor.org/stable/43823948.

Goodale, Mark. 2017. Anthropology and Law: A Critical Introduction. New York: New York University Press. https://doi.org/10.2307/j.cttlggjigh.

Heyman, Josiah McC. 2000. "Respect for Outsiders? Respect for the Law? The Moral Evaluation of High-Scale Issues by US Immigration Officers." Fournal of the Royal Anthropological Institute 6:635-52. https://doi.org/ 10.1111/1467-9655.00037.

Holbraad, Martin, and Morten Axel Pedersen. 2012. "Revolutionary securitization: an anthropological extension of securitization theory." International Theory 4(2):165-97. https://doi.org/10.1017/S1752971912000061. . 2013. Times of Security: Ethnographies of Fear, Protest and the Future. London and New York: Routledge. https://doi.org/10.4324/9780203077856.

Howell, Signe (ed.) 1997. The Ethnography of Moralities. New York: Routledge.

Huysmans, Jef. 2011. "What's in an act? On security speech acts and little security nothings." Security Dialogue 42(4-5):378-83. https://doi.org/ $\underline{10.1177 / 0967010611418713 .}$.

Illuzzi, Jennifer. 2014. Gypsies in Germany and Italy, 1861-1914: Lives outside the Law. New York and Basingstoke: Palgrave Macmillan. https://doi.org/ $10.1057 / 9781137401724$.

Ivasiuc, Ana. 2015. "Watching over the Neighbourhood: Vigilante Discourses and Practices in the Suburbs of Rome." Etnofoor 27(2):53-72. . 2018. "The Order of Things and People: Urban Surveillance Culture in Europe". On_Culture (Fall 2018). https://www.on-culture.org/journal/issue-6/ivasiuc-the-order/. 
. 2019a. "Sharing the Insecure Sensible: The Circulation of Images of Roma in the Social Media." In The Securitization of the Roma in Europe, edited by Huub van Baar, Ana Ivasiuc, and Regina Kreide, 233-59. London and New York: Palgrave Macmillan. https://doi.org/ 10.1007/978-3-319-77035-2 11.

. 2019b. "Reassembling (In)security: The Power of Materiality." In Conceptualizing Power in Dynamics of Securitization: Beyond State and International System, edited by Regina Kreide and Andreas Langenohl, 367-94. Baden Baden: Nomos. https://doi.org/10.5771/9783845293547-367. - 2020. "Race Matters: The Materiality of Domopolitics in the Peripheries of Rome." International Journal of Urban and Regional Research. $\underline{\text { ht- }}$ tps://doi.org/10.1111/1468-2427.12891.

. forthcoming. "From Folk Devils to Modern State Devils: The Securitization and Racial Policing of the Roma in Italy." In Modern Folk Devils: The Construction of Evil in Contemporary Europe, edited by Martin Demant Frederiksen and Ida Harboe Knudsen. Helsinki: Helsinki University Press.

Kapferer, Bruce, and Marina Gold. 2018. Moral Anthropology: A Critique. New York and Oxford: Berghahn Books. https://doi.org/10.2307/j.ctvw04hdc.

Kuldova, Tereza. 2020. "Imposter Paranoia in the Age of Intelligent Surveillance: Policing Outlaws, Borders and Undercover Agents." Journal of Extreme Anthropology 4(1):45-73. https://doi.org/10.5617/jea.7813.

Low, Setha. 2003. Behind the Gates: Life, Security and the Pursuit of Happiness in Fortress America. New York and London: Routledge. https://doi.org/ $10.4324 / 9780203491256$.

Low, Setha, and Mark Maguire. 2019. Spaces of Security: Ethnographies of Securityscapes, Surveillance, and Control. New York: New York University Press. https://doi.org/10.18574/nyu/9781479863013.001.0001.

Lucassen, Leo, Wim Willems, and Annemarie Cottaar. 1998. Gypsies and Other Itinerant Groups: A Socio-Historical Approach. London: Palgrave. https:// doi.org/10.1007/978-1-349-26341-7.

Lyon, David. 2018. The Culture of Surveillance. Cambridge: Polity Press.

Maestri, Gaja. 2019. Temporary Camps, Enduring Segregation: The Contentious Politics of Roma and Migrant Housing. Palgrave Macmillan. https://doi.org/ 10.1007/978-3-030-03736-9.

Maguire, Mark, Catarina Frois, and Nils Zurawski (eds.). 2014. The Anthropology of Security. London: Palgrave. https://doi.org/10.2307/j.ctt183p3j7.

Marani, Alessia. 2019. "Roma, case ai rom: tensioni a Casal Bruciato, il piano della Raggi non ferma le proteste." Il Messaggero, May 7.

Mattingly, Cheryl, and Jason Throop. 2018. "The Anthropology of Ethics and Morality." Annual Review of Anthropology 47:475-92. https://doi.org/ $\underline{\text { 10.1146/annurev-anthro-102317-050129. }}$. 
Mayall, David. 2004. Gypsy Identities 1500-2000. London: Routledge. https:// doi.org/10.4324/9780203490051.

Moffette, David. 2012. "Études critiques de la sécurité: quelques contributions théoriques pour une anthropologie de la sécurité." Aspects sociologiques 19(1):40-69.

Monahan, Torin. 2009. "Identity Theft Vulnerability: Neoliberal Governance through Crime Construction." Theoretical Criminology 13(2):155-176. https://doi.org/10.1177/1362480609102877.

Moore, Jason W. 2017. "The Capitalocene, Part I: On the Nature and Origins of our Ecological Crisis." Fournal of Peasant Studies 44(3):594-630. https:// doi.org/10.1080/03066150.2016.1235036.

Möschel, Matthias. 2014. Law, Lawyers and Race. Critical Race Theory from the United States to Europe. Milton Park, Abingdon, Oxon, and New York (NY): Routledge. https: / /doi.org/10.4324/9781315816739.

Nader, Laura. 2002. The Life of the Law. Berkeley and Los Angeles (CA): University of California Press.

Narotzky, Susana, and Paz Moreno. 2002. "Reciprocity's Dark Side: Negative Reciprocity, Morality and Social Reproduction." Anthropological Theory 2(3):281-305. https://doi.org/10.1177/1463499602002003801.

Okely, Judith. 1983. The Traveller-Gypsies. Cambridge: Cambridge University Press. https://doi.org/10.1017/CBO9780511621789.

Palazzo, Francesco. 2011. Codice penale 1930: un passato (ancora) senza futuro. Diritto Penale Contemporaneo. https://archiviodpc.dirittopenaleuomo.org/d/ 851-codice-penale-1930-un-passato-ancora-senza-futuro. Accessed June 20 2020.

Parsons, John R. 2020. "Border Militias Experience, Narrative, and the Moral Imperative to Act." Fournal of Extreme Anthropology 4(1):1-21. https:// doi.org/10.5617/jea.7350.

Piasere, Leonardo. 2009(2004). I Rom d'Europa: una storia moderna. Roma and Bari: Laterza.

- 2011. "Horror infiniti. Die Zigeuner als Europas Trickster." behemoth 4(1):57-85. https://doi.org/10.1515/behemoth.2011.005.

- 2012. Scenari dell'antiziganismo. Tra Europa e Italia, tra antropologia e politica. Florence: SEID.

Picker, Giovanni. 2012. "Left-Wing Progress? Neo-Nationalism and the Case of Romany Migrants In Italy." In The Gypsy 'Menace'. Populism and the New AntiGypsy Politics, edited by Michael Stewart, 81-94. London: Hurst \& Company.

Picker, Giovanni, Margaret Greenfields, and David Smith. 2015. "Colonial Refractions: the 'Gypsy Camp' as a Spatio-racial Political Technology.” CITY 19(5):741-52. https://doi.org/10.1080/13604813.2015.1071123. 
Ruggiu, Ilenia. 2016. "Is Begging a Roma Cultural Practice? Answers from the Italian Legal System and Anthropology.” Romani Studies 5, 26(1):31-61. https://doi.org/10.3828/rs.2016.2.

Saletti Salza, Carlotta. 2014. Famiglie amputate. Le adozioni dei minori dal punto di vista dei rom. Rome: CISU.

Scheu, Johannes. 2011. "Dangerous Classes: Tracing back an Epistemological Fear." Distinktion: Scandinavian Fournal of Social Theory 12(2):115-34. DOI: 10.1080/1600910X.2011.572716.

Schwell, Alexandra, and Katharina Eisch-Angus. 2018. Der Alltag der (Un-)Sicherheit: Ethnografisch-kulturwissenschaftliche Perspektiven auf die Sicherheitsgesellschaft. Berlin: Panama Verlag.

Scott, James C. 1987. Weapons of the Weak: Everyday Forms of Peasant Resistance. New Haven (CT): Yale University Press.

Sigona, Nando. 2002. Figli del ghetto: Gli Italiani, i campi nomadi, e l'invenzione degli zingari. Civezzano: Nonluoghi-libere edizioni.

. 2003. "How Can a 'Nomad' be a 'Refugee'? Kosovo Roma and Labelling Policy in Italy." Sociology 37(1):69-79. https://doi.org/ 10.1177/0038038503037001445. 2005. 'Locating 'The Gypsy Problem'. The Roma in Italy: Stereotyping, Labelling and 'Nomad Camps'." Fournal of Ethnic and Migration Studies 31(4):741-56. https://doi.org/10.1080/13691830500109969.

Simoni, Alessandro (ed.). 2005. Stato di diritto e identità rom. Turin: L'Harmattan.

- 2008. "I decreti emergenza nomadi: il nuovo volto di un vecchio problema." Diritto immigrazione e cittadinanza 10(3-4):44-56. . 2010-2011. "Appunti per una 'lettura romanì' del pacchetto sicurezza." In Fura Gentium: La "minoranza insicura": I rom e $i$ sinti in Europa, edited by Nicola Fiorita, Orsetta Giolo, and Lucia Re VIII:30-41.

_ 2011a. "Roma and Legal Culture: Roots and Old and New Faces of a Complex Equality Issue." European Anti-Discrimination Law Review 13:11-19. . 2011b. "Il 'problema di una gente vagabonda': Retrospettiva sulla percezione degli 'zingari' nella cultura giuridica italiana.” In La condizione giuridica dei Rom e Sinti in Italia, edited by Paolo Bonetti, Alessandro Simoni, and Tommaso Vitale, 225-54. Milan: Giuffrè.

Solimene, Marco. 2011. “These Romanians have ruined Italy’: Xoraxané Romá, Romanian Roma and Rome." Journal of Modern Italian Studies 16(5):637-651. http://dx.doi.org/10.1080/1354571X.2011.622471.

Stasolla, Carlo. 2012. Sulla pelle dei Rom. Rome: Alegre.

Sykes, Karen. 2009. Ethnographies of Moral Reasoning: Living Paradoxes of a Global Age. London: Palgrave Macmillan. https://doi.org/10.1057/9780230617957.

Tesăr, Cătălina. 2015. "Begging - Between Charity and Profession: Reflections on Romanian Roma's Begging Activities in Italy.” In The Public Value of Anthro- 
pology: Engaging Critical Social Issues through Ethnography, edited by Elisabeth Tauber and Dorothy Zinn, 83-109. Bolzano: Bolzano University Press. Thomassen, Bjørn. 2015. "Begging Rome: Norms at the Margins, Norms of the In-between." Critique of Anthropology 35(1):94-113. https://doi.org/ $\underline{10.1177 / 0308275 X 14557090 .}$.

Tosi Cambini, Sabrina. 2008. La zingara rapitrice: racconti, denunce, sentenze (19862007). Rome: CISU.

- 2011. "The social dangerousness of the defendant is 'at one with her own condition of being nomadic'." Journal of Modern Italian Studies 16(5):652-66. https://doi.org/10.1080/1354571X.2011.622472. . 2015. "Lo spazio del razzismo: Il trattamento dei corpi (degli) altri nel governo della città." In Il colore della nazione, edited by Gaia Giuliani, 15771. Milan: Mondadori.

. 2017. "La dimensione politica della mendicità: Contributo alla ridefinizione del fenomeno in rapporto al governo della città." Minority Reports. Cultural Disability Studies 5:113-42.

Trevisan, Paola. 2017. "'Gypsies' in Fascist Italy: from expelled foreigners to dangerous Italians." Social History 42(3):342-64. https://doi.org/ 10.1080/03071022.2017.1327643.

Trucco, Lorenzo. 2008. "Legal and Policy Developments in the Condition of Migrants and Roma in Italy." Roma Rights 2:31-4.

van Baar, Huub. 2011. "Europe's Romaphobia: Problematization, securitization, nomadization." Environment and Planning D: Society and Space 29(2):203-12. https://doi.org/10.1068/d2902ed1.

Wacquant, Loïc. 2009. Punishing the Poor: The Neoliberal Government of Social Insecurity. Durham (NC): Duke University Press. https://doi.org/ $\underline{10.1215 / 9780822392255 .}$.

Wolf, Eric R. 1982. Europe and the People without History. Berkeley: University of California Press.

Zigon, Jarrett. 2008. Morality: An Anthropological Perspective. Oxford and New York: Berg. 2010. "Moral and ethical assemblages: A response to Fassin and Stoczkowski." Anthropological Theory 10(1-2):3-15. https://doi.org/ $10.1177 / 1463499610370520$.

Zuboff, Shoshana. 2019. The Age of Surveillance Capitalism: The Fight for a Human Future at the New Frontier of Power. New York: Public Affairs. 